\title{
AMYOTROPHIC LATERAL SCLEROSIS IN A BRAZILIAN KAYAPÓ-XIKRIN NATIVE
}

\author{
Clecio Godeiro-Junior?, João Paulo B. Vieira-Filho', Andre Carvalho Felício', Acary S.B. Oliveira
}

Amyotrophic lateral sclerosis (ALS) is one of the major neurodegenerative disorders alongside Alzheimer's disease and Parkinson's disease. It is a progressive disorder that involves degeneration of motor system at all levels, leading to muscle weakness and fatal course. Physical signs of this disease thus encompass both upper and lower motor neurons.The former is characterized by brisk reflexes and signs of pyramidal release such as Babinski sign, and the latter by muscle atrophy and fasciculation'. The diagnostic criteria for ALS were published elsewhere ${ }^{2}$.

The incidence of sporadic ALS is between 1.5-2/ 100000 per year, giving a prevalence of around 6/100000. Males are usually more affected than females (ratio 1.6:1)'. In Brazil, an attempt to put together a comprehensive database to assess ALS's epidemiological aspects was performed. The incidence and prevalence were lower than in Europe and USA. Regarding the clinical characteristics the same clinical pattern as in European and North-American patients was found. Minor differences in Brazilian patients were found on their lower age at onset and a higher incidence of bulbar onset among women ${ }^{3}$.

Several causal and pathogenic hypotheses for ALS have been proposed over the years, ranging from genetic to environmental etiology. Approximately 5-10\% patients with the diagnosis of ALS present a positive family history. Autosomal recessive and dominant pattern of inheritance were already described. Between $10-20 \%$ of autosomal-dominant patients have mutations in superoxide dismuatse (SOD1) gene on chromosome 21. Numerous other genetic mutations were reported: angiogenin (14q11.2), vascular endothelial growth factor (6p12), survival motor neuron (5q12.2-q13.3), neurofilament protein (22q12.2), and charged multivesicular body protein $2 \mathrm{~B}(2 \mathrm{p} 11.2)^{4}$. A host of environmental factors have been investigated as potential risk factors, ranging from heavy-metal toxic effects to occupational exposures. Current research are focusing largely on excitotoxicity and oxidative stress, even the cycad exposure has been revisited ${ }^{5,6}$. Chomorros, a native population of Guam Island, were the first group in which a clear environmental toxin exposure was related to increased risk of $\mathrm{ALS}^{6}$. In Brazil, there is no description of a native group with increased risk of ALS.

Herein we describe the first report of ALS in a Brazilian native of the Xikrin group. This group of natives belongs to a larger group known as Kayapó from "Jê" linguistic family. Their village extends along the Catete river, in eastern Amazonia, State of Para, north of Brazil. The Xikrin were almost extinct by 1968, reaching the number of only $98^{7}$. However, in the last four decades, with an appropriate health support, their population has been increasing due to a great number of births and reduction in infantile mortality, reaching a total population of 947 natives (512 male and $435 \mathrm{female}$ ) in July $2007^{\circ}$. Figure shows Xikrin village during a traditional ritual for old and young men.

\section{CASE}

A 46-year-old female Xikrin native presented a 4-month history of progressive burning pain in the gluetal region and progressive loss of strength on four limbs. Two weeks before admission she required assistence rising from a sitting position and a increased fatigue developed. She also presented urinary in-

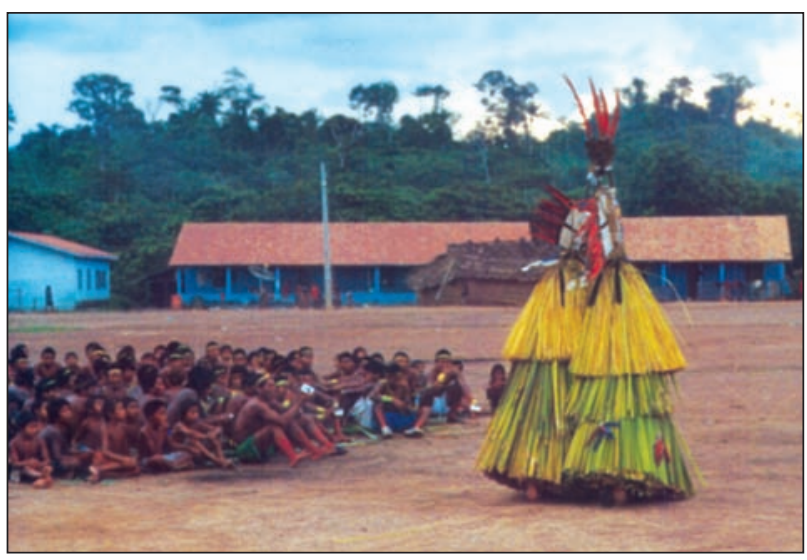

Figure. Xikrin village in state of Pará, north of Brazil, during a traditional ritual for men.

\section{ESCLEROSE LATERAL AMIOTRÓFICA EM UMA ÍNDIA BRASILEIRA XIKRIN-KAYAPÓ}

'Department of Neurology and Neurosurgery, Federal University of São Paulo, São Paulo SP, Brazil; ${ }^{2}$ Service of Endocrinology, Federal University of São Paulo, São Paulo SP, Brazil.

Received 17 April 2008, received in final form 18 July 2008. Accepted 24 July 2008.

Dr. Clecio Godeiro-Junior - Rua Dr Diogo de Faria 650 / 33 - 04037-002 São Paulo SP - Brasil. E-mail: cleciojunior@yahoo.com.br 
continence. Family history and past medical history were unremarkeble.

Her vital signs and mental status were normal. Neurological examination disclosed diffuse muscle atrophy and the widespread fasciculations were presented in the arms and legs. Muscle strength was grade III proximal and IV distal in upper limbs, and grade II proximal and I distal in lower limbs. Reflexes were globally brisk and bilateral Babinski sign was presented. Signs of Hoffman and Wartenberg were also present. Cranial nerve examination was normal, excepet that her speech occasionaly seemed slightly slurred. Sensory examination was normal. Joint-position sence was intact in the arms and legs. Parkinsonian facies or increased motor tone were not noted.

Magnetic resonance imaging (MRI) of the brain showed no abnormalities. Multilevel MRI of the spine presented mild degenrative articular disease of the cervical spine, but no evidence of marked central channel stenosis or an abnormal cord signal detected. A complete blood count was normal. Levels of serum sodium, potassium, calcium, magnesium, phosphorus, creatine kinease, vitamin B12, folate, glucose, thyroid-stimulating hormon, creatine and imunnoglobulines were normal, as were the results of liver function tests and serum electrophoresis. Cerebrospinal fluid analysis was unremarkable.

Nerve condution studies and electromyography (EMG), was preformed. Motor nerve condution studies showed normal distal latencies and velocities with low amplitudes of the compound muscle action potential. Sensory conduction studies were normal. EMG showed spontaneous activity (fibrilations and positive sharp waves), abundant fasciculations, changes in the configuration of motor unit potentials and decreased recruitment pattern indicative of a net motor unit loss, in the four limbs. These findings were consistent with a generalized disorder of the lower motor neurons, their axons, or both, as seen in ALS, progressive muscular atrophy, or pure motor axonal neuropathy.

This patient's syndrome of progressing upper and lower motor neuron dysfunction in mutiple anatomical regions supported a dignosis of ALS of sporadic variety, according to the El Escorial criteria for $\mathrm{ALS}^{2}$.

We obtained informed conset from the patient for publishing this article.

\section{DISCUSSION}

We present an unique occurrence of ALS in a Brazilian female native from a particular region of Brazil.

Current epidemiological data on ALS in Brazil do not include our native population since most of surveys were preformed in referral centers. Regional published data concerning ALS mortality in Brazil, where it is fairly reliable (São Paulo and Rio de Janeiro cities), infers an incidence rate of $0.3-0.5 / 100000$ population. Considering the mean duration of the disease to be 3 years, this yields a disease prevalence of about 1,440 to 2,400 cases in Bra- sil (0.9 to $1.5 / 100000$ inhab), lower than that described in Europe and USA ${ }^{3}$.

Brazilian's series of ALS shows a higher prevalence of ALS in males and the age of disease onset age around the fourth decade, except in the series of Castro-Costa and coworkers that showed a high percentage of young cases, sporadic juvenile and early-onset adults with ALS 9 . In Brazil, limb onset is more frequent and survival after diagnoses lasts around 48 months ${ }^{3,9-11}$. Our patient presents particular characteristics: a female native manifesting a disease occuring in earlier age.

The multifactorial etiology of ALS lies on a complex interplay between genetical and environmental causes. The absence of family history and no other patient in his tribe with ALS does not give us a hint of a possible mechanism to explain the development of disease in this unique ethnic group. A previous report of Vieira-Filho and coworkers $^{12}$ showed two Brazilian natives of the Xavantes group who developed polyneuropathy related initially to thiamin deficiency. In their report, the authors identified that the consume, almost exclusively, of manufactured rice, poor in thiamine, contributed to development of this polyneuropathy. In latter study a hereditary pattern was identified in these patients, characterizing a hereditary sentive and motor polyneuropathy (Vieira-Filho, personal comunication).

In Chomorro group, the habit of ingesting fox-bats which consume cycad, a fruit rich in oxidant substances, was pointed as responsible etiology of ALS in that population $^{6}$. The Xikrin feeding habits include fish consume. Most of rivers in eastern Amazonia pass through gold mines, although Cateté river does not, where mercury is used to extract gold. Could consume of intoxicated fishes be responsible for neurodegenerative diseases in this population? We do not have the answer for this question yet. These natives also consume wild mammals such as dolmen, jaw, deer, caititu, paca and cotia. Could a mechanism similar to that of Guam island exist in Xikrin region? It is only certain that the Xikrin village was submitted to pulverization with pesticides such as organophosphates during campaing against vectors of malaria among natives ${ }^{8}$.

In our report, normal complementary exams and abnormal EMG, suggests that the clinical manifestations are secondary to a neurodegenerative disorder of the upper and lower motor system, probably ALS. We wonder if Xikrin working habits could contribute to the disease. An interesting observation of Werneck et al." and Vieira-Filho $^{12}$ drives us to a few hypothesis. In Werneck's report, statistical relationships were found between heavy occupations, such as agricultural, forestery and fishery workers, and males with $\mathrm{ALS}^{11}$. In native communities men are 
responsible for hunting and agriculture such as reported by Vieira-Filho and coworkers ${ }^{4}$. On the other hand, women have a hard occupation in agriculture, hand craft and taking care of children ${ }^{12}$. More specific association of ALS with different occupation have appeared in some casecontrol studies. Thus, ALS has appeared as associated with heavy manual work, electric trauma, employment in the plastic industry, exposure to heavy metals, acids and animal carcasses, high increased exercises as seen in soccer player ${ }^{13,14}$. Particularly, in soccer players, ALS presents earlier onset. It is speculated that extreme physical exercise, as seen in soccer players or in indian population could facilitate the development of this disease ${ }^{15}$.

We could not deny a possible genetic predisposition for our patient. But genetic studies and clinical examination of other members of the tribe would be necessary. The Xikrin-Kayapó tribe represents a small group of natives and consanguineous marriages may be frequent, increasing the chance of emerging new gene mutations. It is worthwhile to mention that these speculative genetic factors could also be protective as well for the development of neurodegenerative diseases such as ALS.

Although our report does not present any new information regarding clinical presentation of ALS, its importance lies on the ethnic group in which the disease was found. A better analysis of Xikrin-Kayapó habits and genetic characteristics could give us important clues in the understanding of ALS physiopathology.

\section{REFERENCES}

1. Mitchell JD, Borasio GD. Amyotrophic lateral sclerosis. Lancet 2007; 369:2031-2041.

2. Brooks BR, Miller RG, Swash M, Munsat TL;World Federation of Neurology Research Group on Motor Neuron Diseases. El Escorial revisited: revised criteria for the diagnosis of amyotrophic lateral sclerosis. Amyotroph Lateral Scler Other Motor Neuron Disord 2000;1:293-299.

3. Dietrich-Neto F, Calegaro D, Dias-Tosta E, et al. Amyotrophic lateral sclerosis in Brazil: 1998 national survey. Arq Neuropsiquiatr 2000;58: 607-615.

4. Figlewicz DA, Orrel OW. The genetics of motor neuron diseases. Amyotroph Lateral Scler Other Motor Neuron Disord 2003;4:225-231.

5. Arnon C. Environmental risk factor for amyotrophic lateral sclerosis. Neuroepidemiology 2001;20:2-69.

6. Borenstein AR, Mortimer JA, Schofield E, et al. Cycad exposure and risk of dementia, MCI, and PDC in the Chamorro population of Guam. Neurology 2007;68:1764-1771.

7. Vieira-Filho, JPB. Os dermatoglifos palmares situando os índios brasileiros Xikrin no contexto mundial. Tese. São Paulo, 1969.

8. http://www.socioambiental.org/pib/epi/xikrin/cont.shtm (accessed in March $\left.18^{\text {th }}, 2008\right)$

9. Castro-Costa CM, Oria RB, Machado-Filho JA, et al. Amyotrophic lateral sclerosis: clinical analysis of 78 cases from Fortaleza (northeastern Brazil). Arq Neuropsiquiatr 1999;57:761-774.

10. Lima JMB, Mesquita N, Duro LAA, Furtado AB. Epidemiological aspects of ALS in Rio de Janeiro City. Rev Bras Neurol 1983;19:75-78.

11. Werneck LC, Bezerra R, Silveira O Neto, Scola RH. A clinical epidemiological study of 251 cases of amyotrophic lateral sclerosis in the south of Brazil. Arq Neuropsiquiatr 2007;65:189-195.

12. Vieira-Filho JPB, Oliveira ASB, Silva MRD, Amaral AL, Schultz RR. Polineuropatia nutricional entre índios Xavantes. Rev Ass Med Brasil 1997;43:82-88.

13. Sutedja NA, Veldink JH, Fischer K, et al. Lifetime occupation, education, smoking, and risk of ALS. Neurology 2007;69:1508-1514.

14. Weisskopf MG, McCullough ML, Morozova N, Calle EE, Thun MJ, Ascherio A. Prospective study of occupation and amyotrophic lateral sclerosis mortality. Am J Epidemiol 2005;162:1146-1152.

15. Chiò A, Benzi G, Dossena M, Mutani R, Mora G. Severely increased risk of amyotrophic lateral sclerosis among Italian professional football players. Brain 2005;128:472-476. 